\title{
Muscular Partitioning in the Semitendinosus Muscle of the Pig
}

\author{
Compartimientos Musculares del Músculo Semitendinoso del Cerdo \\ Guillermo H. Graziotti; Clara M. Ríos; José M. Rodríguez Menéndez; Matías A. Salinas; \\ Alexis Bosco; Alejandra Paltenghi Ceschel; Néstor O. Affricano \& Carlos L. Victorica
}

GRAZIOTTI, G. H.; RÍOS, C. M.; RODRÍGUEZ M. J. M.; SAliNAS, M. A.; BOSCO, A.; PALTENGHI, C. A.; AFFRICANO, N. O. \& VICTORICA, C. L. Muscular partitioning in the semitendinosus muscle of the pig. Int. J. Morphol., 27(3):947-953, 2009.

SUMMARY: Neuromuscular compartments are subvolumens supplied by a primary nerve branch with homogeneous fiber characteristics. This muscular organization is important for understanding the muscle function in relation to postural and dynamic implications and also is relevant for appraising meat quality. Current researches associate fiber muscle characteristics with perimortem processes that regulate muscle transformation into meat. It is known that pig muscle has four heavy chain myosin isoforms: I, IIa, IIx and IIb. Castrated male pigs were slaughtered at $100 \mathrm{~kg}$ live weight. Semitendinosus muscle samples of each subvolumen determined previously (R1, R2, R3, R4) were frozen in liquid nitrogen and reacted for myofibrillar ATPase and NADH-TR for determining fiber types and oxidative capacity respectively. It were identified I, IIA and IIX/IIB fiber types. The frequency distribution of the I, IIA, and IIX/IIB fiber types were significantly greater in R1- R4, R4 and R3 respectively. The CSA of all fiber types was significantly larger in R1 than other compartments, notwithstanding CSA did not vary significantly among fiber types; oxidative capacity was significantly greater in R4. These results show a heterogeneousness of the muscle which would explain probably the disagreements documented between characteristics of fiber and meat quality traits.

KEY WORDS: Pig; Semitendinosus muscle; Muscle fibers; Meat quality.

\section{INTRODUCTION}

The researches made by English \& Letbetter (1982) have been used as base line to subsequent studies about neuromuscular partitioning and architectural design of skeletal muscles. Roy et al. (1984), Hermanson (1997), Bruce et al. (1993) and Kernell (1998) define the neuromuscular compartment as a muscle subvolumen supplied by a primary muscular nerve branch with homogeneous fibers and a characteristic architecture. Generally, the compartments are composed by long parallel fibers or by short oblique fibers, associated with greater capacity for shortening or isometric contraction respectively (Roy et al.; Roy \& Ishihara, 1997). These variations in muscular organization, important for understanding the muscle function in relation to postural and dynamic implications, have also significance in meat quality traits. Current researches (Karlsson et al., 1999; Cerisuelo et al., 2007; Hu et al., 2008; Wimmers et al., 2008) have associated fiber muscle characteristics with biochemical and physical perimortem processes that regulate the transformation of muscle into meat.
In recent years has been documented (Lefaucheur $e t$ al., 1998; Graziotti et al., 2001; Quiroz-Rothe \& Rivero, 2004; Abreu et al., 2006; Hu et al.) that pig skeletal muscle is composed by four heavy chain myosin isoforms, I, IIa, IIx and IIb, giving the pure fiber types I, IIA, IIX and IIB, and its hybrid forms; their oxidative capacity is I $>$ IIA $>$ IIX $>$ IIB. Nevertheless, the identification between IIX and IIB types is not reliable by using only histochemical methods (Gil et al., 2001; Lefaucheur et al., 2002).

The aim of this research has been to determine the fiber characteristics of pig semitendinosus muscle (SMP), one of the most studied in meat quality investigations for applying in functional and husbandry studies.

\section{MATERIAL AND METHOD}

Gross anatomy.The right SMP was removed from five 
carcasses preserving the sciatic nerve branches and muscle subvolumens were identified in agreement with Graziotti et al. (2007). In brief, muscles were cleaned of fat and connective tissues, immersed in a $10 \%$ formalin solution during 30 days, rinsed with tap water for 3 hours, gone under a $25 \%$ nitric acid solution during 10 days, checking each 48 hours (Hermanson). Macroscopic dissections were carried out following the primary branches of the sciatic nerve.

Histochemistry and Image Analyses. This research was conducted on 87 castrated male pigs INTA-MGC genetic line and killed at $100 \mathrm{~kg}$ live weight. Muscle samples $\left(1 \mathrm{~cm}^{3}\right)$ were obtained from the core of each subvolumen determined previously of right SMP within 6 hs after slaughtering and rolled in talcum power, immersed in liquid nitrogen (Ronéus \& Essén Gustavsson, 1997), and stored at $-80^{\circ} \mathrm{C}$ until analysis. Frozen samples were transferred to a Reichert Jung 1800 cryostat at $-27^{\circ} \mathrm{C}$; serial cross sections at $10 \mathrm{~mm}$ thickness were obtained and mounted on coated glass slides for histochemistry. Sections were reacted by qualitative myofibrillar ATPase histochemistry after acid ( $\mathrm{pH} 4.2-4.6,2$ minutes) and basic ( $\mathrm{pH}$ 10.4-10.6, 10 minutes) preincubations by using a modification (Nwoye et al., 1982) of the Brooke \& Kaiser (1970) method for identifying muscle fiber types. Other additional serial sections were also stained by nicotinamide adenine dinucleotide tetrazolium reductase (NADH-TR) activity (Blanco et al., 1988) to appraise oxidative capacity. Images of each section were captured in TIFF format (150 pixels/inch) employing the Motic Image plus 2.0 software. From the myofibrillar ATPase staining after acid preincubation (100X) a fiber mask was drawn along the cell borders of the desired number of fibers (at less 100) for determining the cross sectional area (CSA). The mean optical density (OD) was measured on NADH-TR $40 \mathrm{X}$ images drawing a mask along the border that includes three adjacent fascicles. This technique was adopted due to muscle fiber types are not distributed at random; anaerobic fibers are housed in neighborhood of the perimisium (McConathy et al., 1983). All measures were done by grayscale using an image-analyzing software processing (public domain Scion Image v. Beta 3b software, available for Windows). It was used at 0.367 and 0.680 pixels/ $\mu \mathrm{m}$ scales for $40 \mathrm{X}$ and $100 \mathrm{X}$ images for NADH-TR and mATPase respectively. Pennation fiber angle was measured over a digital image using software (Motic Image plus 2.0). Fiber type distribution, CSA, and oxidative capacity were analyzed by one way ANOVA. Significant differences among subvolumens were stablished using Tukey's test $(\mathrm{p}<0.05)$.

\section{RESULTS}

The obtained results are showed in figures 1, 2, 3, 4 and tables I and II. In brief, in each axial half of the muscle two compartments were determined, proximal and distal; R1, proximal-medial; R2, proximal-lateral; R3, distal-lateral and R4, distal-medial (Fig. 1). These compartments were identified according to the distribution of the primary branches of the sciatic nerve. Each compartment had fibers arranged in parallel. Nevertheless, inside R4 an oblique muscular bundle with a $24.5^{\circ}$ pennation angle ran caudoventrally toward fibers condensation place that were going to integrate the common calcanean tendon (CCT) (Fig. $2 \mathrm{a}, \mathrm{b})$. A vestigial tendinous intersection was observed on the medial edge of the medium third of the muscle (Fig. 1, it).

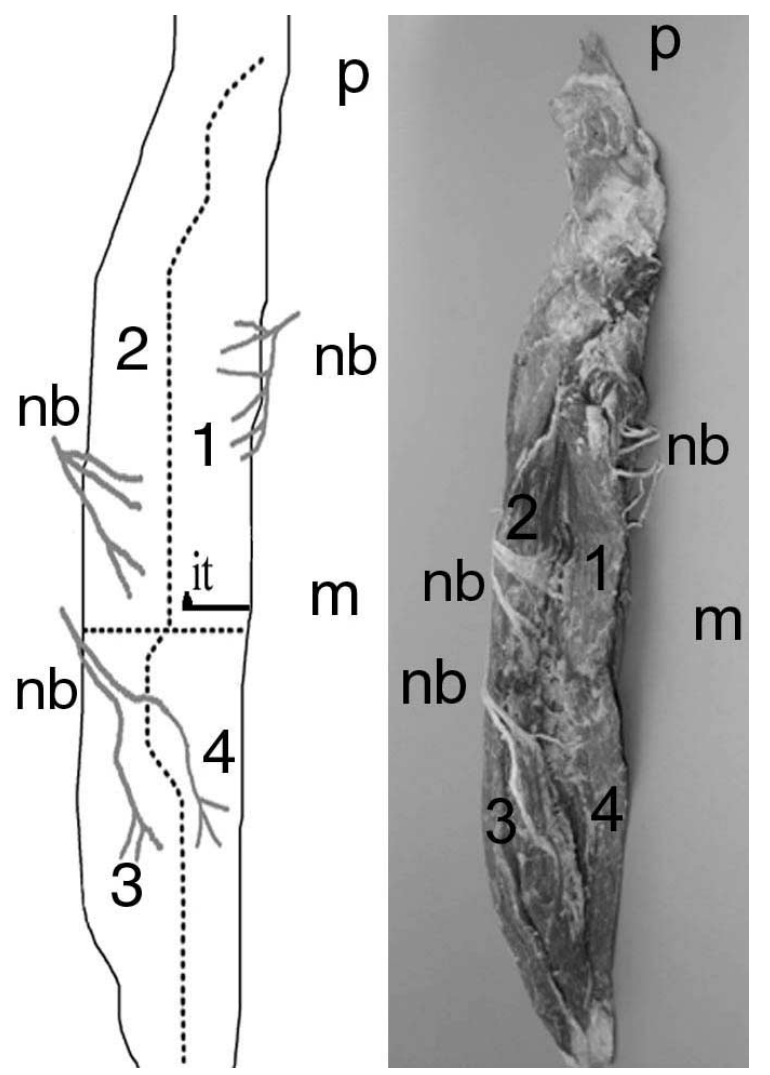

Fig. 1. Neuromuscular compartments in SMP. Squeme to the left and muscle after treatment with nitric acid to the right. R1 (1), R2 (2), R3 (3), R4 (4); nb, indicates primary muscle branches of the sciatic nerve; it, rudimentary tendinous intersection; $\mathrm{p}$, proximal; $\mathrm{m}$, medial.

Table I. Frequency distribution and fiber type characteristics (CSA and DO). Its significant differences considered by muscle regions. CSA measured in mm2. Means with the same letter are not statistically different. Standard errors (SE) are indicated between brackets.

\begin{tabular}{lccllc}
\hline & Type I & Type IIA & Type IIB/IIX & CSA & DO \\
\hline R1 & $20.75^{\mathrm{a}}$ & $12^{\mathrm{ab}}$ & $39.25^{\mathrm{a}}$ & $8372.28^{\mathrm{a}}(490.16)$ & $110.18^{\mathrm{a}}(6.46)$ \\
R2 & $7.25^{\mathrm{b}}$ & $10.25^{\mathrm{a}}$ & $59.38^{\mathrm{ab}}$ & $6056.97^{\mathrm{b}}(357.71)$ & $87.59^{\mathrm{a}}(4.76)$ \\
R3 & $6.75^{\mathrm{b}}$ & $8.5^{\mathrm{a}}$ & $74.25^{\mathrm{b}}$ & $6241^{\mathrm{b}}(303.62)$ & $88.94^{\mathrm{a}}(5.48)$ \\
R4 & $35.5^{\mathrm{a}}$ & $23.375^{\mathrm{b}}$ & $38.88^{\mathrm{a}}$ & $5281.70^{\mathrm{b}}(261.95)$ & $139.94(4.63)$ \\
\hline
\end{tabular}




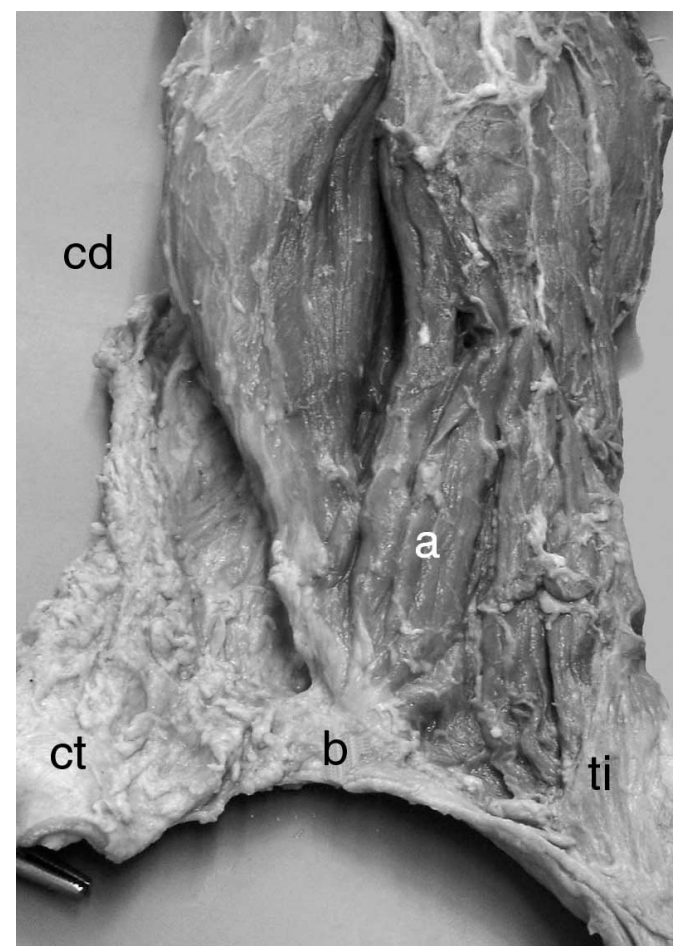

Fig. 2. R4 compartment of the SMP, medial aspect. Muscle bundles (a) to the common calcanean tendon (ct) and its tendon (b); tibial insertion (ti), caudal border (cd).

It were identified I, IIA and IIX/IIB fiber types (Fig. 3). The frequency of I fiber type was significantly greater in R1 and R4, the frequency of IIA fiber type was significantly larger in R4, and the frequency of IIX/IIB fiber type was significantly increased in R3 (Table I). The CSA of the different fiber types did not vary significantly (Table II). However, the CSA of all fiber types in R1 was significantly greater than the remainder compartments (Table I); oxidative capacity was significantly larger in R4 (Table I, Fig. 4).

\section{DISCUSSION}

The semitendinosus muscle of small mammals as rabbit, mouse, rat and guinea pig has a complex architectural design. Roy et al. have been documented the existence of a tendinous intersection, which divide the belly muscle into proximal-distal compartments. Between them vary the characteristics of the fibers; inside the proximal compartment exists a
Table II. Cross sectional area fibers (CSA) indicate areas for each fiber type without discriminating by regions. CSA measured in $\mathrm{mm}^{2}$. There are not statistical differences. Standard errors (SE) are indicated between brackets.

\begin{tabular}{lccc}
\hline & Tipo I & Tipo IIA & Tipo II B/IIX \\
\hline CSA & 6886.84 & 6100.11 & 6477.68 \\
& $(394.85)$ & $(371.22)$ & $(343.13)$ \\
\hline
\end{tabular}

subvolumen clearly oxidative. In the cat semitendinosus muscle English \& Weeks (1987) described the existence of two subvolumens, proximal and distal separated by a tendinous intersection, which is rudimentary in dog (Barone, 1996), and pig (Graziotti et al., 2007).

In the present research, the methodology utilized did not allow to identify between the types IIX and IIB, so it were considered statistically as a single group. Nevertheless Graziotti et al. (2001) have distinguished between IIX and IIB fiber types by histochemistry in pig longissimus muscle. Due to the plasticity of the ATPase system (Müntener, 1979), for obtaining a similar identification in the SMP probably should be achieved a more adequate combination between preincubation and incubation $\mathrm{pHs}$.

In the SMP, the muscle fibers have uniform and parallel disposition, corresponding according to Roy \& Ishihara, to fast shortening compartments. Though, in the present results, the fibers type population presents an axial lateromedial distribution, with significant predominance of I and IIA fiber types in medial compartments, while in lateral ones exist a greater significant proportion of glicolitic IIX/IIB fibers. The axial arrangements about fiber type characteristics obtained in the present research have been reported in limb muscles of other mammals. (Hermanson; Kernell; Wang \& Kernell, 2000; Graziotti et al., 2004).

The existence of two fast architectural compartments (R1 and R4) with oxidative fibers (I and IIA) is in accordance with Burkholder et al. (1994) who document that architecturally fast muscles do not necessarily coincide with fast fibers, that is to say, that the type of fibers is not always a complement of the length of the fibers.

Wang \& Kernell document the eccentric concentration of type I fibers in rat hindlimb muscles, being more evident as much as more remote is the muscle from the axis of the hindlimb. It could explain the significant concentration of oxidative fibers (I and IIA) in R1 and R4.

At the same time exists a proximo-distal arrangement of the fiber types; though both medial compartments have a predominant oxidative metabolism, only the ventral one (R4) has statistical significance. Also CSA in R1 is significantly greater than others.

Even so, as only one muscle sample was analyzed from each compartment, our results do not exclude the possible existence of a 

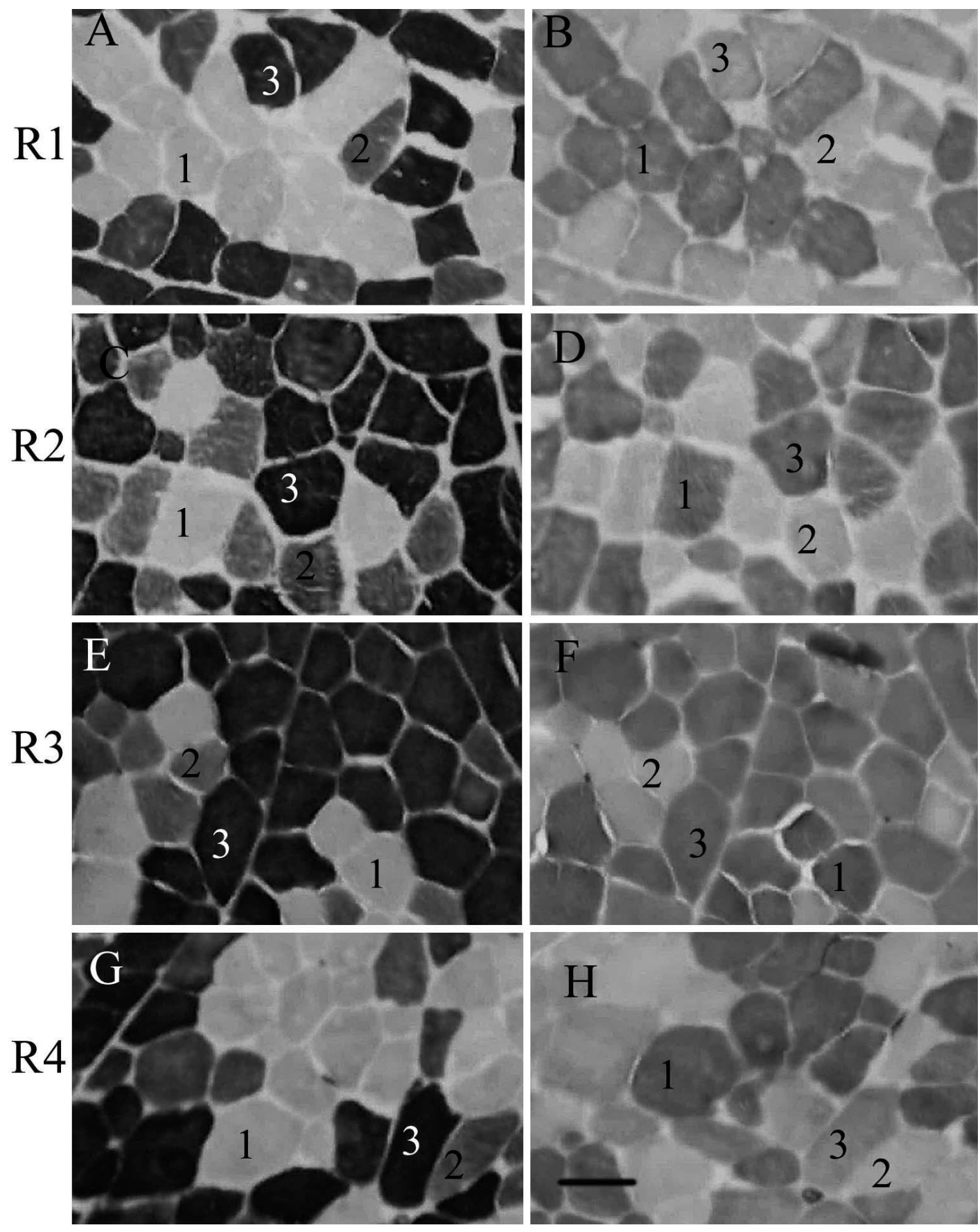

Fig. 3. Identification of myofiber types by myofibrillar ATPase activity after preincubation at $\mathrm{pH}$ 10,4 (A, $\mathrm{C}, \mathrm{E}, \mathrm{G})$ and $\mathrm{pH} 4,5$ (B, D, F, H) in serial cross-sections of the four neuromuscular compartments (R1, R2, R3, R4) of the SMP. Type I (1), Type IIA (2) and Type IIX/IIB (3). Scale bar 100 $\mu$ m.

more gradual modification of the proportion of fibers toward the limits of the subvolumens, denominated by Kernell fiber regionalization.

It is interesting to emphasize that greater fiber pennation in the core of R4 (Fig. 2), which contribute in the formation of CCT coincides with the predominant phenotype of I and IIA oxidative fibers (Fig. 3, 4). The I fiber type predominance in R4 is explained by its greater efficiency to carry out isometric contractions improving the specific tension/ATP consumption relation, with regard to fibers IIA and IIX (Bottinelli \& Reggiani, 2000). These results could be compared with those obtained by Abreu et al. where a greater oxidative capacity were documented in the pig biceps 


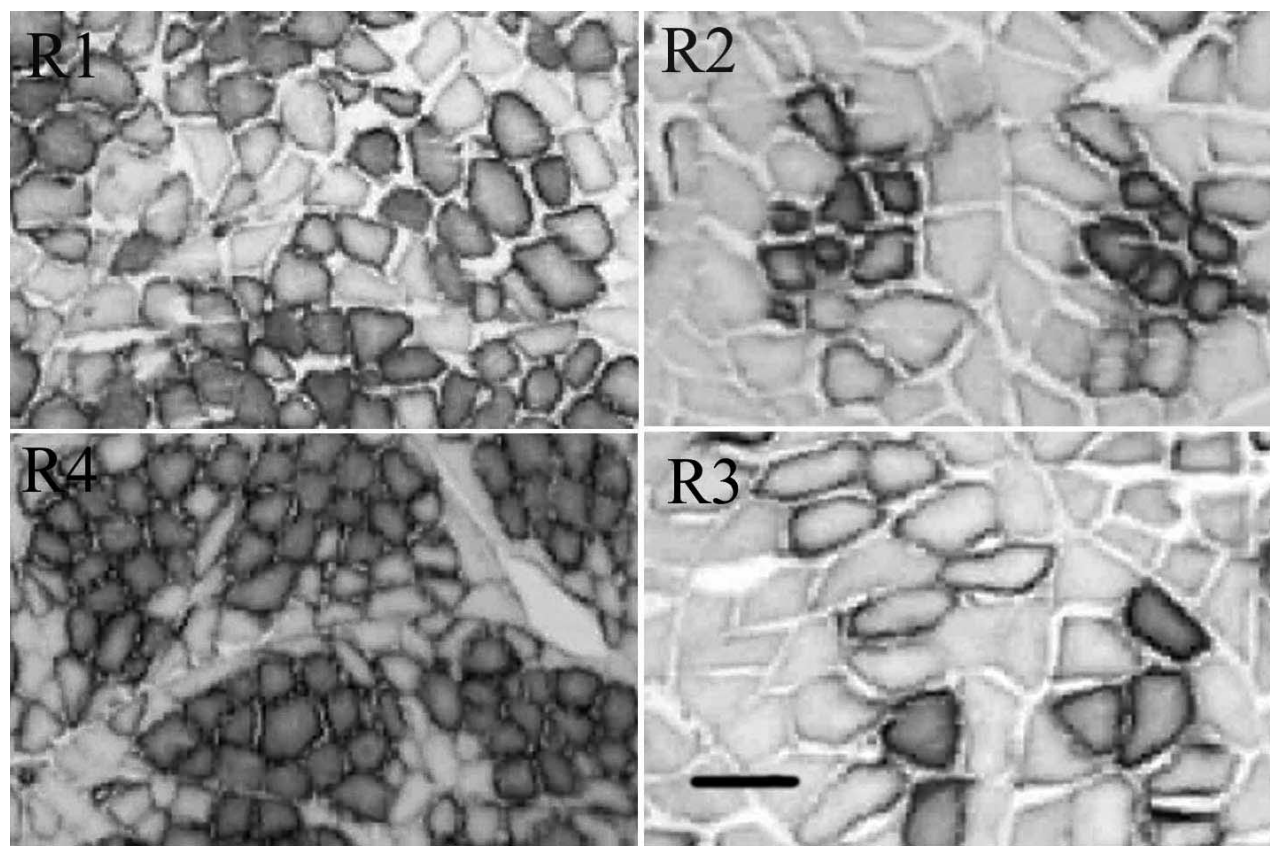

Fig. 4. Serial cross-sections of the four neuromuscular compartments (R1, R2, R3, R4) of the SMP stained by $\mathrm{NADH}-\mathrm{TR}$ reaction. Note the darker NADH-TR histochemical reaction in $\mathrm{R} 4$. Scale bar $250 \mu \mathrm{m}$. femoris muscle with regard to the semimembranosus, probably due to their isometric antigravitatory action as component of the CCT. Notwithstanding, these authors did not carry out a compartmentalized study of these muscles.

These divisions among neuromuscular compartments without a complete relationship between architectural desing and fiber types, emphasize the supremacy of the architectural muscle design over the fiber types, as the appendicular muscles show in the mouse (Burkholder et al.).

The documented disagreements between fiber characteristics and meat quality traits (Gentry et al., 2004; Cerisuelo et al.), could be probably explained by a lack of prior anatomical studies on architectural design and fiber muscle characteristics as we have done in this research.

This study can be useful like base line for future works in meat technology and besides to offer a new perspective for muscle fiber researches.

ACKNOWLEDGMENTS. This work was funded by grants V-803 and G-010 from University of Buenos Aires (U.B.A.C.Y.T). The authors thank the muscular samples transfer to the Dr. Campagna from University of Rosario and Marco Juárez INTA Station, Argentina. Likewise we thank to the Area of Histology, Faculty of Veterinary Sciences, UBA, by permitting us the use of the cryostat.

GRAZIOTTI, G. H.; RÍOS, C. M.; RODRÍGUEZ M. J. M.; SAlinAS, M. A.; BOSCO, A.; PALTENGHI, C. A.; AFFRICANO, N. O. \& VICTORICA, C. L. Compartimientos musculares del músculo semitendinoso del cerdo. Int. J. Morphol., 27(3):947-953, 2009.

RESUMEN: Los compartimientos neuromusculares son subvolúmenes abastecidos por un ramo nervioso primario, los cuales poseen características fibrilares homogéneas. Esta organización muscular es importante para entender la función muscular en relación tanto en la estática y dinámica como en la apreciación de la calidad de la carne. Actuales investigaciones asocian características fibrilares con procesos perimorten que regulan la transformación del músculo en carne. Es conocido que en el músculo del cerdo están presentes cuatro cadenas pesadas de miosina: I, IIa, IIx y IIb. Cerdos machos castrados fueron faenados a los 100K kg de peso vivo. Muestras musculares de cada subvolumen del músculo semitendinoso, previamente determinados (R1, R2, R3, R4), fueron congeladas en nitrógeno líquido y tratadas con las reacciones de ATPasa miofribrilar y NADH-TR para determinar los tipos fibrilares y la capacidad oxidativa, respectivamente. Fueron identificadas los tipos fibrilares I, IIA y IIX/IIB. La frecuencia de distribución de los tipos fibrilares I, IIA, y IIX/IIB fueron significativamente mayores en R1- R4, R4 y R3, respectivamente. La CSA de todos los tipos fibrilares fueron significativamente mayores en R1 que en los otros compartimientos, sin embargo CSA no varía en forma significativa entre los tipos fibrilares; la capacidad oxidativa fue significativamente mayor en R4. Estos resultados evidencian una heterogeneidad muscular la cual podría probablemente explicar los desacuerdos documentados entre las características de las fibras y su relación con la evaluación de la calidad de la carne.

PALABRAS CLAVE: Porcino; Músculo semitendinoso; Fibras musculares; Calidad de la carne. 
GRAZIOTTI, G. H.; RíOS, C. M.; RODRíGUEZ M. J. M.; SALINAS, M. A.; BOSCO, A.; PALTENGHI, C. A.; AFFRICANO, N. O. \& VICTORICA, C. L. Muscular partitioning in the semitendinosus muscle of the pig. Int. J. Morphol., 27(3):947-953, 2009.

\section{REFERENCES}

Abreu, E.; Quiroz-Rothe, E.; Mayoral, A. I.; Vivo, J. M.; Robina, A.; Guillen, M. T.; Agüera, E. \& Rivero J. L. L. Myosin heavy chain fibre types and fibre sizes in nuliparous and primiparous ovariectomized Iberian sows: interaction with two alternative rearing systems during the fattening period. Meat Sci., 74:359-72, 2006.

Barone, R. Anatomie Comparée des Mammifères Domestiques, Arthrologie Myologie. Vigot, París, 1996.

Blanco, C. E.; Sieck, G. C. \& Edgerton, V. R. Quantitative histochemistry determination of succinic dehydrogenase activity in skeletal muscle fibres. Histochem. J., 20:23043, 1988.

Bottinelli, R. \& Reggiani, C. Human skeletal muscle fibres: molecular and functional diversity. Prog. Biophys. Mol. Biol., 73:195-262, 2000.

Brooke, M. H. \& Kaiser, K. K. Muscle fiber types: how many and what kind?. Arch. Neurol., 23:369-79, 1970.

Bruce, V. L.; Turek, R. J \& Schurg, W. A. Muscle fibre compartmentalization in the gluteus medius of the horse. Equine Vet. J., 25:69-72, 1993.

Burkholder, T. J.; Fingado, B.; Baron, V. \& Lieber, R. Relationship between muscle fiber types and sizes and muscle architectural properties in the mouse hindlimb. J. Morphol., 221:177-90, 1994.

Cerisuelo, A.; Sala, V.; Nürnberg, G.; Baucells, V. \& Rehfeldt, V. How many muscle samples are required to obtain reliable estimations of muscle fibre characteristics from pig longissimus muscle?. Meat Sci., 76:583-7, 2007.

English, A. W. \& Letbetter, W. D. Anatomy and innervation patterns of cat lateral gastrocnemius and plantaris muscles. Am. J. Anat., 164:67-77, 1982.

English, A. W. \& Weeks, O. I. An anatomical and functional analysis of cat biceps femoris and semitendinosus muscles. J. Morphol., 191:161-75, 1987.

Gentry, J. G.; McGlone, J. J.; Miller, M. F. \& Blanton, J. R. Jr. Environmental effects on pig performance, meat quality and muscle characteristics. J. Anim. Sci., 82:209-17, 2004.

Gil, F.; López Albors, O.; Vázquez, J. M.; Latorre, R.; Ramírez Zarzosa, G. \& Moreno, F. The histochemical profiles of fibre types in porcine skeletal muscle. Histol. Histopathol., 16:439-42, 2001.

Graziotti, G. H.; Delhon, G.; Ríos, C. M. \& Rivero, J. L. Fiber muscle types in adult female pigs as determined by combinating histochemical and immunohistochemical methods. Rev. Chil. Anat., 19:167-73, 2001.

Graziotti, G. H.; Palencia, V.; Delhon, V. \& Rivero, J. L. Neuromuscular partitioning, architectural design, and myosin fiber types of the M. vastus lateralis of the llama (Lama glama). J. Morphol. 262:667-81, 2004.

Graziotti, G. H.; Rodríguez Menéndez, J. M.; Ríos, C. M.; Salinas, M.; Paltenghi Ceschel, A.; Affricano, O.; Bosco, A.; Victorica, C. \& Basso, L. Perfil metabólico del músculo semitendinoso del cerdo. In. Vet., 9:19-26, 2007.

Hermanson, J. W. Architecture and the division of labor in the extensor carpi radialis muscle of horses. Acta Anat., 159:127-35, 1997.

Hu, H.; Wang, J.; Zhu, R.; Guo, J. \& Wu, Y. Effect of myosin heavy chain composition of muscles of meat quality in Laiwu pigs and Duroc. Sci. China C. Life Sci., 51:12732, 2008.

Karlsson, A. H.; Klont, R. E. \& Fernandez, X. Skeletal muscle fibres as factors for pork quality. Livest. Prod. Sci., 60:255-69, 1999.

Kernell, D. Muscle regionalization. Can. J. Appl. Physiol., 23:1-22, 1998.

Lefaucheur, L.; Hoffman, R. K.; Gerrard, D. E.; Okamura, C. S.; Rubinstein, N. \& Kelly, A. Evidence for three adult fast myosin heavy chain isoforms in type II skeletal muscle fibers in pigs. J. Anim. Sci., 76:1584-93, 1998.

Lefaucheur, L.; Ecolan, V.; Plantard, V. \& Gueguen, N. New insights into muscle fiber types in the pig. J. Histochem. Cytochem., 50:719-30, 2002.

McConathy D.; Giddings, C. J. \& Gonyea, W. J. Structurefunction relationships of the flexor carpi radialis muscle compared among four species of mammals. J. Morphol., 175:279-92, 1983.

Müntener, M. Variable pH dependence of the mATPase in different muscles of the rat. Histoch., 62:299-304. 1979. 
Nwoye, L.; Mommaerts, W. F.; Simpson, D. R.; Serayderian, K. \& Marusich, M. Evidence for a direct action of thyroid hormone in specifying muscle properties. Am. J. Physiol., 242:R401-8, 1982.

Quiroz-Rothe, E. \& Rivero, J. L. Coordinated expression of myosin heavy chains, metabolic enzymes, and morphological features of porcine skeletal muscle fiber types. Microsc. Res. Tech., 65:43-61, 2004.

Ronéus, N. \& Essén Gustavsson, B. Skeletal muscle characteristics and metabolic response to exercise in young standardbreds. Am. J. Vet. Res., 58:167-70, 1997.

Roy, R. R.; Powell, P. L.; Kanim, P \& Simpson, D. R. Architectural and histochemical analysis of the semitendinosus muscle in mice, rats, guinea pigs, and rabbits. J. Morphol., 18:155-60, 1984.

Roy R. R. \& Ishihara, A. Overview: functional implications of the design of skeletal muscles. Acta Anat., 159:75-7, 1997.

Wang L. \& Kernell, D. Proximo-distal organization and fibre type regionalization in rat hindlimb muscles. J. Muscle Res. Cell Motil., 21:587-98, 2000.

Wimmers K.; Ngu, N. T.; Jennen, D. G.; Tesfaye, V.; Murani, E.; Schellander, K. \& Ponsuksili, S. Relationship between myosin heavy chain isoform expression and muscling in several diverse pig breeds. J. Anim. Sci., 86:795-803, 2008.
Correspondence to: Guillermo H. Graziotti

Area of Anatomy, Faculty of Veterinary Science

Buenos Aires University (UBA).

Chorroarín 280

Ciudad de Buenos Aires

CWO 1427,

ARGENTINA

Email: ggrazio@fvet.uba.ar

Received: 09-03-2009

Accepted: 27-07-2009 
